\title{
Influence of silicon and addition elements on the mechanical behavior of ferritic ductile cast iron
}

\author{
A. Alhussein ${ }^{\mathrm{a}, \mathrm{b}, *}$, M. Risbet ${ }^{\mathrm{a}}$, A. Bastien ${ }^{\mathrm{c}}$, J.P. Chobaut ${ }^{\mathrm{c}}$, D. Balloy ${ }^{\mathrm{d}}$, J. Favergeon ${ }^{\mathrm{a}}$ \\ a Université de Technologie de Compiègne, Centre de Recherche Royallieu, Laboratoire Roberval, 60205 Compiègne, France \\ b Institut Charles Delaunay, Laboratoire des Systèmes Mécaniques et d'Ingénierie Simultanée, Université de Technologie de Troyes, UMR 6281, CNRS, Antenne de Nogent, Pôle \\ Technologique de Haute-Champagne, 52800 Nogent, France \\ ${ }^{\mathrm{c}}$ CRITT METALL 2T, IJL, Parc de Saurupt, CS 50840, 54011 Nancy, France \\ ${ }^{\mathrm{d}}$ Ecole centrale de Lille, LML, 59650 Villeneuve d'Ascq, France
}

\begin{abstract}
A B S T R A C T
An experimental study of mechanical properties and microstructural analysis was carried out on different compositions of ferritic spheroidal graphite cast iron. The influence of silicon on the ductility and strength of the material was noticed. The observation of microstructure and failure modes allowed us to explain the important role of chemical composition on the initiation and propagation of cracks. The high silicon segregation between the graphite nodules and the joints of eutectic cells decreases the mechanical material resistance. A metallurgical development was indispensable and necessary to ensure characteristics conformed to the industrial requirements.
\end{abstract}

\section{Introduction}

The goal of our research project called 'SIMAFOND' is to develop a new composition of ductile cast iron. In order to produce industrial pieces more resistant according to the customers' requirements, it was necessary to research a new composition of these products. In this study we present how the ductile iron GJS 500-14 was developed to get the mechanical properties of the other grade GJS 600-10 [1]. The main objective is to investigate the effect of varying silicon content (more than 3.50\%) in ductile iron on mechanical properties and microstructure. The aim is to determine the range of silicon in iron which allows it to have good properties (strength, ductility and resilience).

The spheroidal graphite cast iron is an alloy composed essentially of iron, carbon and silicon which leads to a solidification according to the stable $\mathrm{Fe}-\mathrm{C}$ diagram with formation of graphite. During the casting procedure, treating the molten metal with magnesium provides the spheroidizing of graphite [2-4]. Some elements like nickel, copper and molybdenum are added with a small quantity $(0.1-1 \%)$ to improve slightly or greatly some mechanical characteristics [3,4]. Other elements like calcium, cerium, aluminum and barium are intentionally added with a very small quantity $(0.003-0.1 \%)$ to enhance the formation of graphite. These additions complete with the effect of silicon, increase the number of small spheroids of graphite and refine the microstructure of ductile iron [3]. On the other side, other elements which are presents naturally or accidentally disrupt the good solidifica-tion of the metal. These elements are at different levels of percentage such as manganese, phosphorus, chromium, vanadium and titanium. It is important to note that an alloy element added higher than the required quantity may be harmful to the micro-structure and mechanical properties.

The particularity of the ductile cast iron is related to the morphology of graphite in the form of spheres which allow it to have a better resistance than the morphology in the form of flakes (gray iron) [5,6]. This last one creates notch effects and leads to rupture. The form of spheroidal graphite gives iron special properties which are two to four times more important than these of traditional lamellar or gray iron [5,6]. The induced improvement in mechanical strength of ductile iron allows it to compete with some steels at a much lower manufacturing cost.

By increasing the silicon content the material resilience decreases. The dynamic impact properties of ferritic cast iron are affected by the quantity of graphite nodules and the nodularity [2,7]. The larger the nodules are and/or the fewer in numbers, the lower 
the mechanical characteristics of the iron are. Further, the more the form of the graphite deviates from the ideal spherical shape, the more ductility and strength decrease [2,8-11]. This is due to stress concentration caused by the non-spherical nodules. Khalil-Allafi and Amin-Ahmadi [12] have shown that increasing the silicon content in the range of $2.1-3.3 \%$ led to the increase in graphite nodule count and graphite size.

In this paper, the study is focused on a ferritic ductile iron. The ferrite (alpha iron) has a good ductility (plasticity) and a very good ability to resist the impact energy at low temperatures. The presence of a small quantity of residual pearlite in the ferrite matrix may change the tensile properties and resilience of ductile iron. It increases material hardness and reduces the impact energy necessary to failure [13,14]. Gonzaga and Carrasquilla [15] have shown that manganese with phosphorus promotes the formation of pearlite, but the effect of combination of these two elements is eliminated by the action of silicon.

\section{Characterization of mechanical properties}

Mechanical properties of ductile cast iron were obtained from the following mechanical tests: Uniaxial tensile test and Charpy impact test. From the tensile test, three principal characteristics were particularly followed:

- Tensile strength $\left(\sigma_{u}\right)$ which corresponds to the maximum stress achieved during tensile test.

- Yielding stress $\left(\sigma_{e}\right)$ which corresponds to the elasticity limit or plasticity threshold.

- Failure strain denoted A\%, which corresponds to the plastic deformation of sample measured after rupture.

The impact test is necessary to characterize the dynamic resistance of material. It determines the energy required to fracture a test sample. This test was carried out using a square section sample impacted by a hammer. The ratio between the impact energy and the sample's section area gives the resilience of material.

In order to do this study, cast samples were made in the shape of round bar (25 $\mathrm{mm}$ of diameter and $200 \mathrm{~mm}$ long) [1]. Table 1 presents the chemical compositions of ductile iron. As shown in this table, the chemical composition of $\mathrm{C}, \mathrm{Si}, \mathrm{Mn}, \mathrm{Cu}$ and $\mathrm{Ni}$ was modified. The goal was to improve mechanical properties of iron to achieve these of the grade GJS 600-10 [1]. Table 2 presents the minimum required values of tensile and impact properties.

\subsection{Static characteristics}

Tensile tests were carried out at ambient temperature using cylindrical specimens. According to standards $[1,16]$, specimens were machined from cast samples with $14 \mathrm{~mm}$ of diameter and $70 \mathrm{~mm}$ of gauge length. Figs. 1-3 represent respectively the variation of tensile strength $\left(\sigma_{u}\right)$, yielding stress $\left(\sigma_{e}\right)$ and failure strain (A\%) as a function of increasing silicon content in the material. As shown in these Figures, by increasing silicon content the material strength increases and the ductility decreases.

Table 1

Chemical composition of ferritic ductile iron (wt\%).

\begin{tabular}{llllllllll}
\hline $\mathrm{C}$ & $\mathrm{Si}$ & $\mathrm{Ni}$ & $\mathrm{Cu}$ & $\mathrm{Mn}$ & $\mathrm{P}$ & $\mathrm{S}$ & $\mathrm{Cr}$ & $\mathrm{Mg}$ & $\mathrm{Sn}$ \\
\hline 2.79 & 3.80 & 0.02 & 0.04 & 0.07 & 0.018 & 0.011 & 0.025 & 0.050 & 0.070 \\
- & - & - & - & - & & & & & \\
3.39 & 4.50 & 0.39 & 0.40 & 0.20 & & & & & \\
\hline
\end{tabular}

Table 2

Minimum required values for mechanical properties of ferritic ductile iron [1]

\begin{tabular}{lllll}
\hline Ductile iron & $\begin{array}{l}\text { Tensile } \\
\text { strength (MPa) }\end{array}$ & $\begin{array}{l}\text { Yielding } \\
\text { stress (MPa) }\end{array}$ & $\begin{array}{l}\text { Elongation } \\
\mathrm{A} \%\end{array}$ & $\begin{array}{l}\text { Impact energy } \\
\text { at } 23 \pm 5{ }^{\circ} \mathrm{C}(\mathrm{J})\end{array}$ \\
\hline GJS 600-10 & 580 & 450 & 8 & 70 \\
GJS 500-14 & 480 & 400 & 12 & 80 \\
\hline
\end{tabular}

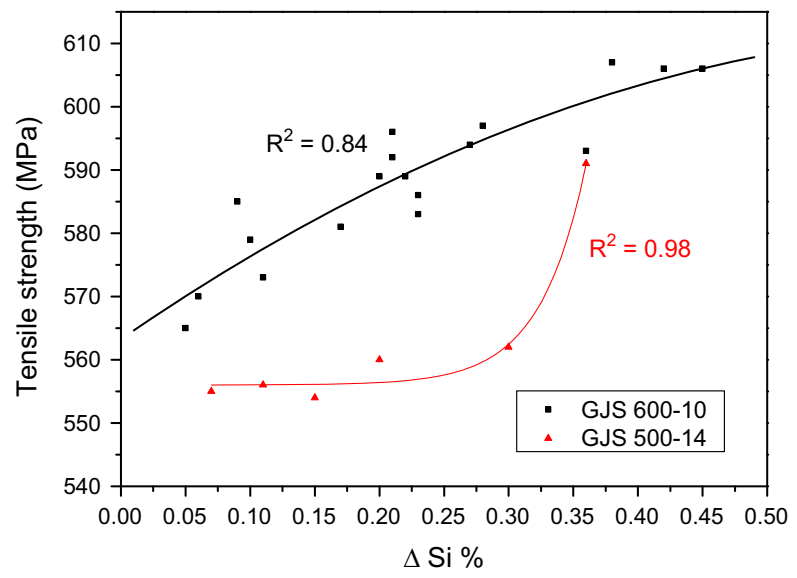

Fig. 1. Increase of tensile strength with increasing silicon content.

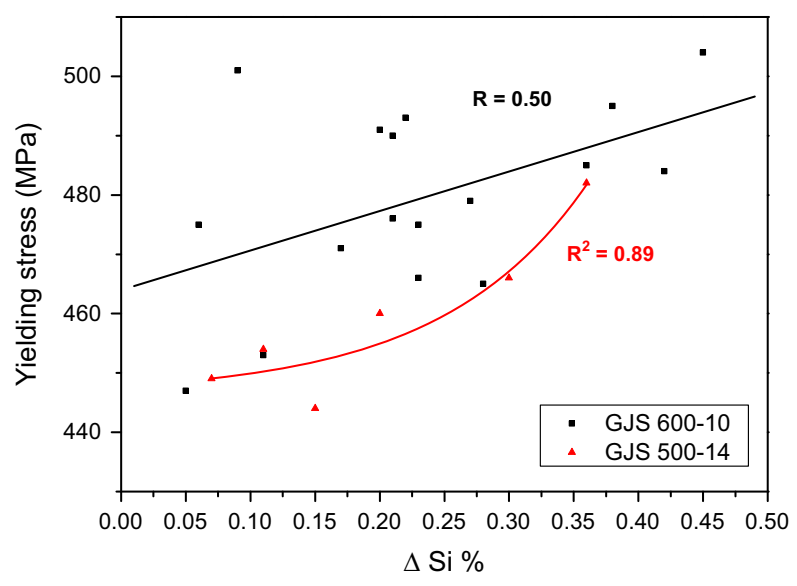

Fig. 2. Increase of yielding stress with increasing silicon content.

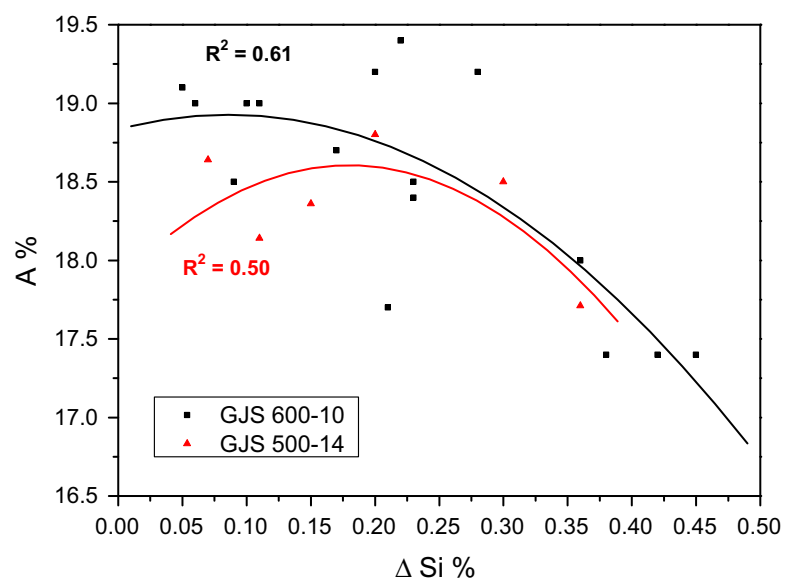

Fig. 3. Variation of failure strain as a function of increasing silicon content. 
It has been shown that increasing silicon content (more than $0.125 \%$ ), Figs. 1 and 2, led to achieve mechanical properties of GJS 600-10 (Table 2). Regarding Fig. 3, the failure strain values are well beyond $16 \%$ on the entire composition range. This good result gives a comfortable margin more important than the minimum values required for both grades of cast iron (Table 2 ). These results showed clearly that it is possible to hold the ultimate strength with a high elongation value.

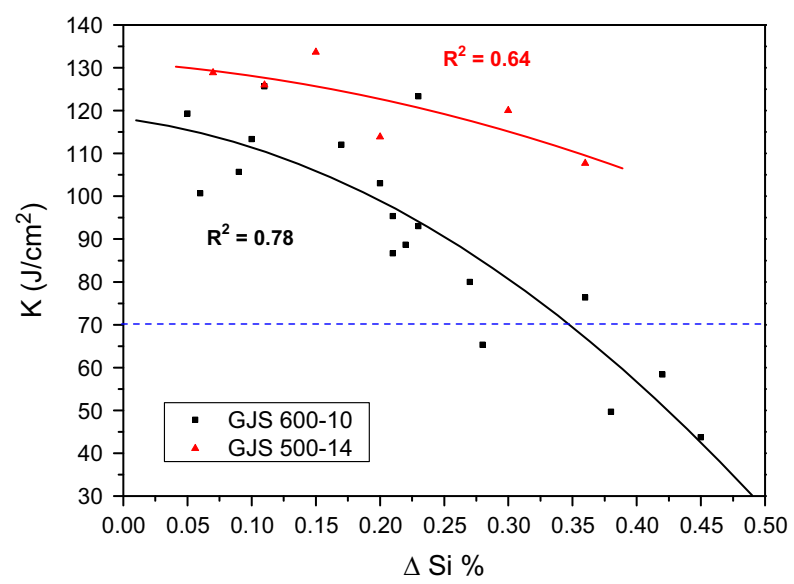

Fig. 4. Influence of silicon content on the resilience of ductile cast iron.

a

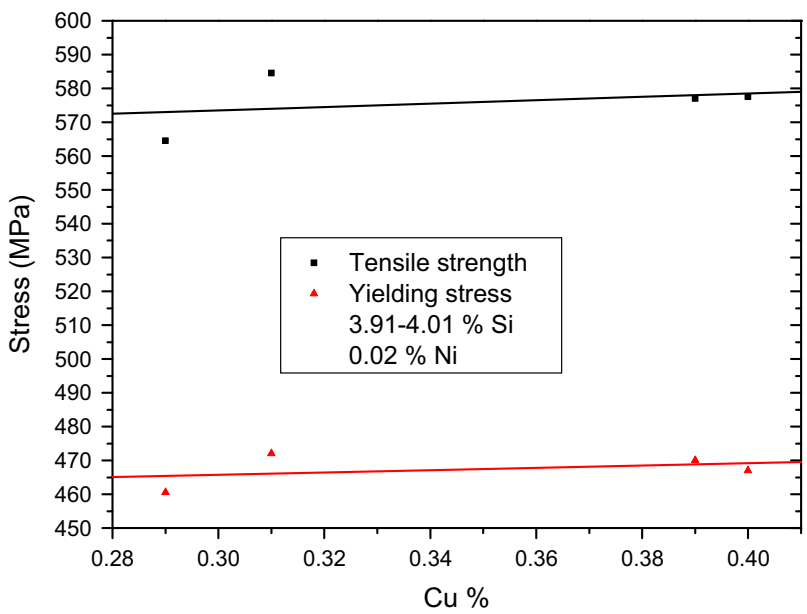

b

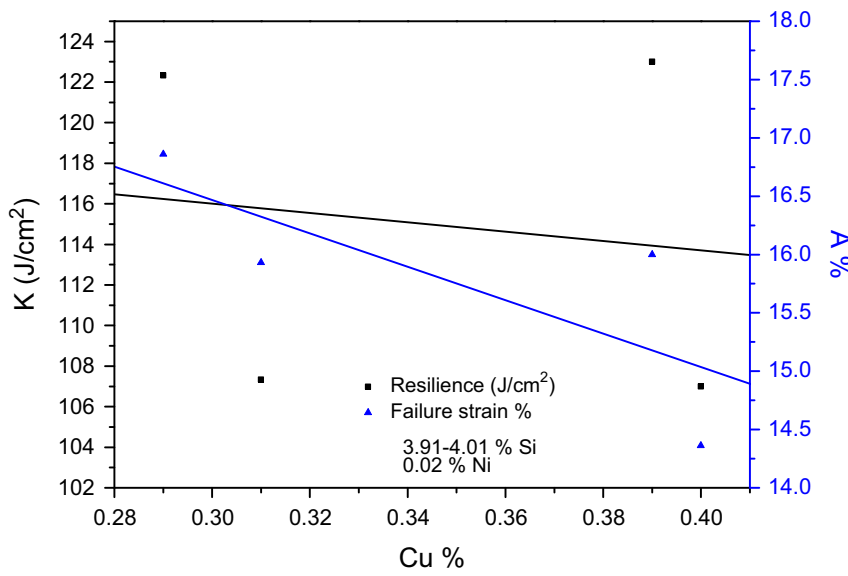

Fig. 5. Influence of copper content on properties of ductile cast iron: (a) tensile strength and yielding stress, and (b) failure strain and resilience.
In fact, it is possible to say that a fairly good correlation between these properties could be shown. For the moment no other correlation appears between the values of $\sigma_{u}$ and chemical composition of cast iron.

\subsection{Dynamic characteristics}

The resilience of a material determines its ability to absorb energy during deformation induced by a shock or dynamic loading. Charpy impact tests were performed at ambient temperature $\left(20^{\circ} \mathrm{C}\right)$ using non-notched Charpy specimens. The dimensions of each specimen in form of parallelepiped are $55 \times 10 \times 10 \mathrm{~mm}^{3}$. Charpy tests were carried out by Zwick RKP 450 machine. The maximal capacity of this machine is $450 \mathrm{~J}$. The knife of striker's head chosen for these tests has an edge radius of $2 \mathrm{~mm}$ [17].

From each cast rod, three Charpy specimens were cut off. Fig. 4 presents the evolution of the resilience $\left(K\right.$ in $\left.J / \mathrm{cm}^{2}\right)$ as a function of increasing silicon content. On this graph, each point represents the resilience average of the three obtained values. We see that increasing the silicon content led to the decrease of material resilience. For high silicon content $(\Delta S i>0.35 \%)$, resilience is too small compared to the minimum required values (Table 2).

The material with $\Delta \mathrm{Si}=0.28 \%$ was broken at impact energy less than $70 \mathrm{~J}$. So to achieve both static and dynamic properties, we determined the range of increasing of silicon content in iron to be

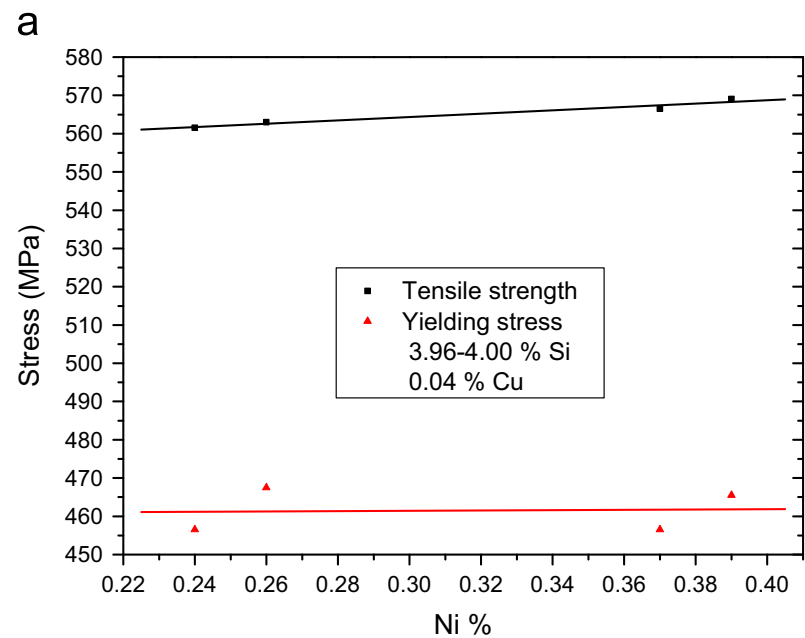

b

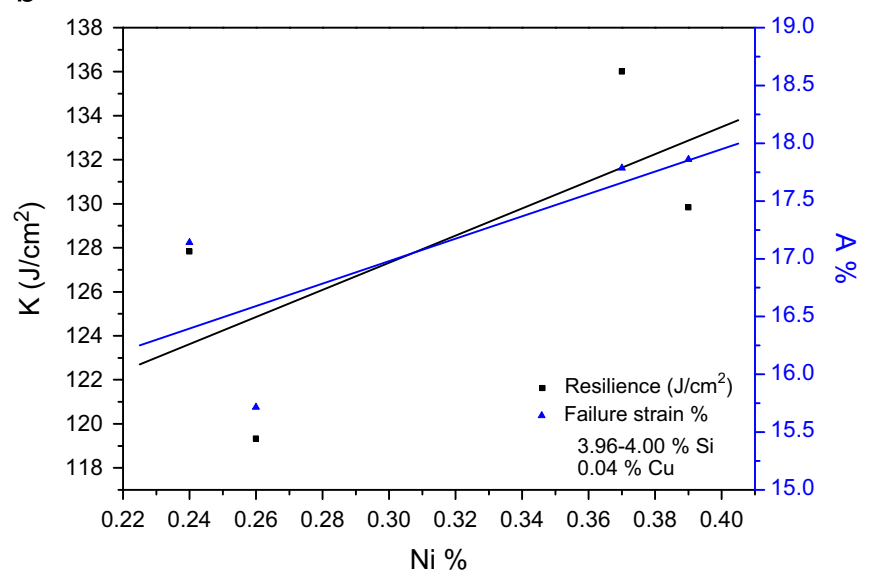

Fig. 6. Influence of nickel content on properties of ductile cast iron: (a) tensile strength and yielding stress, and (b) failure strain and resilience. 


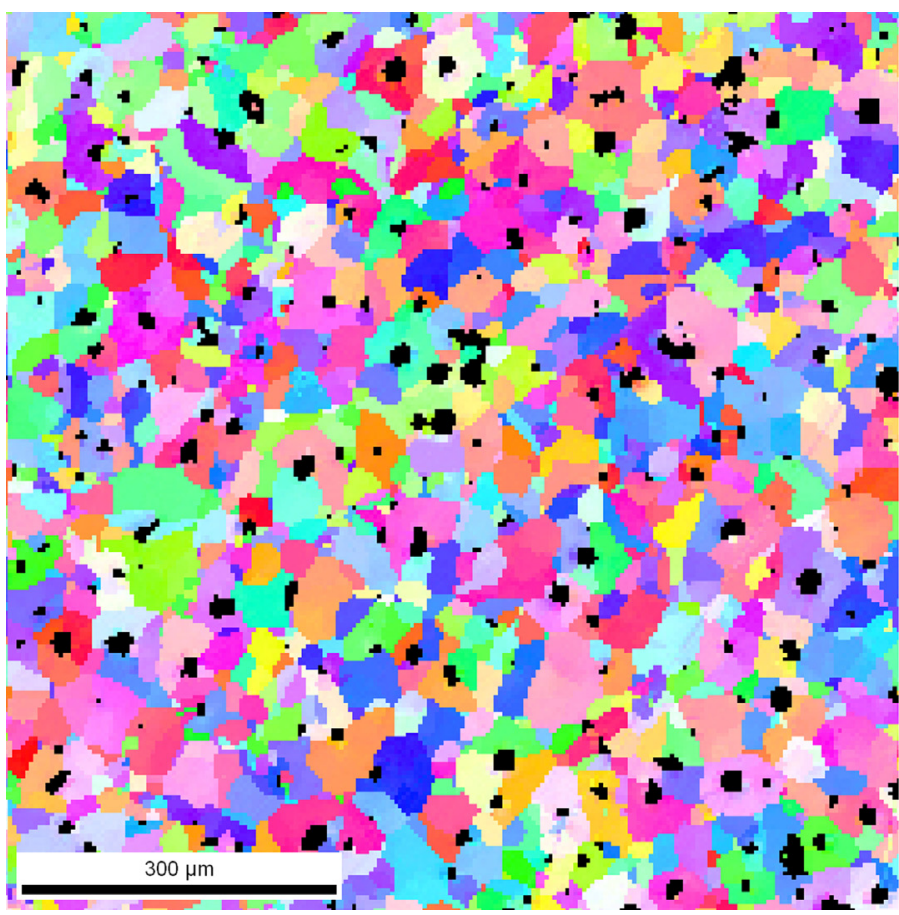

Color Coded Map Type: Imerse Pole Figure [001]

Fenite

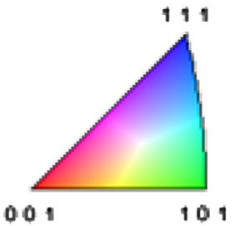

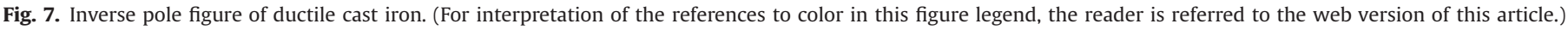

between $0.125 \%$ and $0.25 \%$. Beyond this last value, the change in chemical composition led to worse behavior (Figs. 3 and 4).

\subsection{Effect of residual elements on the strength of ductile cast iron}

Manganese, copper and nickel are the main alloying elements which can harden the ferrite and improve its tensile strength. Manganese must be kept very low to avoid the formation of carbide and pearlite [3,15]. Copper was excluded because $1 \%$ added increases brittle-ductile transition temperature by $45{ }^{\circ} \mathrm{C}$. It can promote the formation of pearlite and reduce ductility and impact toughness [18]. For a similar amount of nickel, transition temperature is increased by $10{ }^{\circ} \mathrm{C}$. Further, nickel can stabilize the pearlite and improve the material impact toughness at low temperature [19]. Moreover, the machinability of cast iron is made more easily with the $\mathrm{Ni}$ than with $\mathrm{Cu}$. For all these reasons, we chose the nickel as a second chemical element controlled with silicon. Figs. 5 and 6 represent the influence of $\mathrm{Cu}$ and $\mathrm{Ni}$ on the mechanical properties (tensile strength, yielding stress, failure strain and resilience) of ductile iron. We see clearly the advantage of $\mathrm{Ni}$ compared to $\mathrm{Cu}$.

\section{Influence of modifications in chemical composition on microstructure}

The evolution of material properties is mainly associated with the changes in microstructure $[3,4,20,21]$. In order to explain the worse behavior of iron (ductility and impact toughness) containing a high silicon ( $\Delta \mathrm{Si} \geq 0.35 \%$ ), we performed the following analysis of microstructures and microfractographies.

\subsection{Ferrite grain size}

The material grain size could be changed by the elements' addition [22]. In order to evaluate the influence of modifications in chemical composition on the ferrite grain size, we studied different compositions of ductile iron which contain different rates of

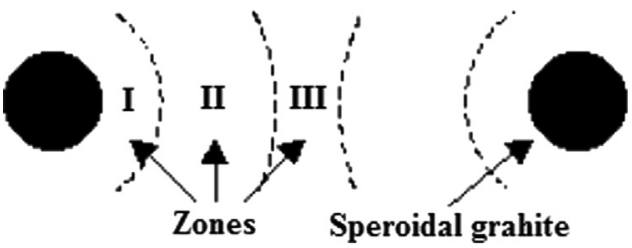

Zone I: closest to the graphite spheroids Zone III: located at the joints of eutectic cells Zone II: intermediate to the two previous

Fig. 8. Silicon segregation zones between two graphite nodules.

silicon. The microstructural analysis was carried out using an optical microscope and a scanning electron microscope. Using both techniques of electron backscatter diffraction (EBSD) and image analysis, it has been shown that the average grain size did not change compared to the conventional composition $(23 \mu \mathrm{m})$. Fig. 7 shows the microstructure of ductile iron analyzed by EBSD technique. In this Figure, the black spots represent the graphite nodules whereas the others colors show the orientation of ferrite grains according to the standard triangle.

\subsection{Influence of silicon segregations on the material hardness}

The segregations of silicon in ductile cast iron weaken its resistance and cause the brittle fracture of material. In fact, the process of solidification leads to segregation of certain alloys' elements, including carbon and silicon. It is possible to divide the matrix of ductile cast iron into three zones of different chemical composition, Fig. 8. The silicon content is high around graphite nodules (zone I) whereas it is low at the joints of eutectic cells (zone III), Figs. 8 and 9 [23].

The phenomenon of segregation influences the heterogeneity of chemical composition of ductile iron, Fig. 9. This Figure represents the segregations of alloying elements between two graphite nodules. We see that $\mathrm{Si}$, Ni and $\mathrm{Cu}$ are highly segregated near graphite nodules contrary to Mn and Mo. 
a

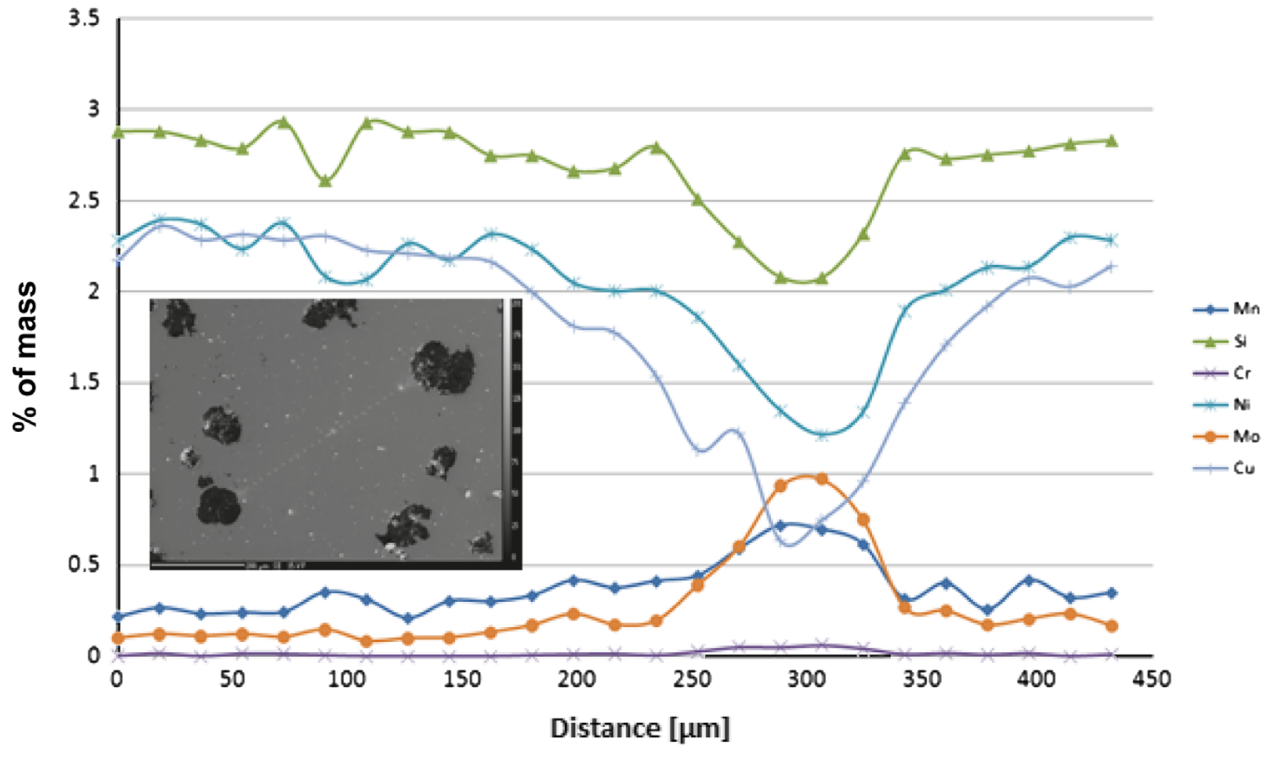

b

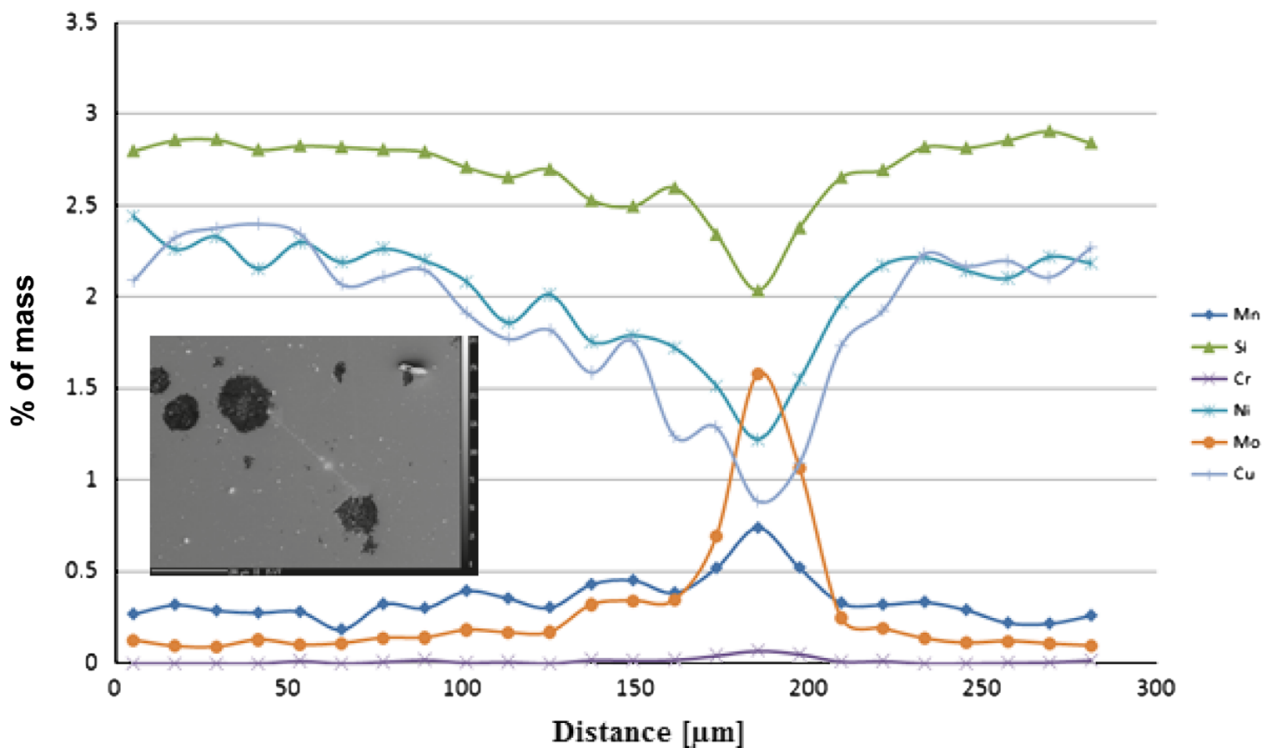

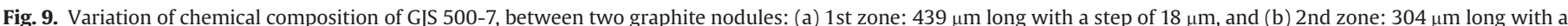
step of $12 \mu \mathrm{m}$.

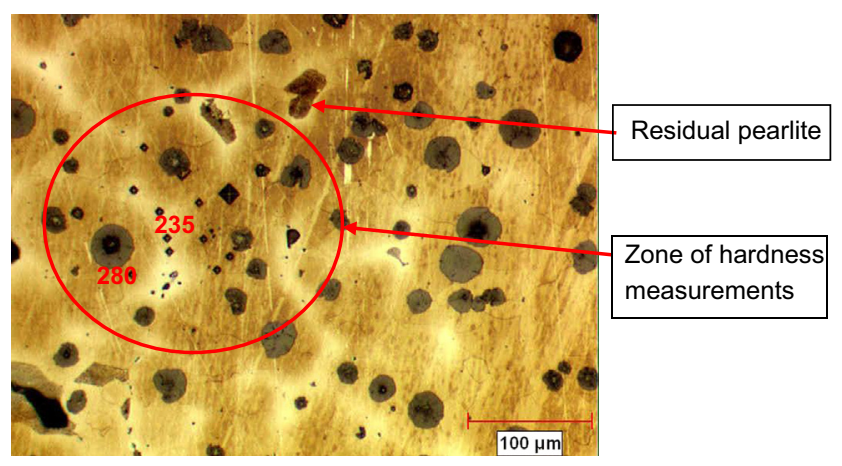

Fig. 10. Micrograph of ductile iron (ferritic matrix with a few darken islands of pearlite). (For interpretation of the references to color in this figure legend, the reader is referred to the web version of this article.)
The segregations of silicon were observed using an optical microscope after etching the surface with Zhou's reagent $(28 \mathrm{~g}$ $\mathrm{NaOH}, 4 \mathrm{~g}$ picric acid, $1 \mathrm{~g} \mathrm{~K}_{2} \mathrm{~S}_{2} \mathrm{O}_{5}$ and $100 \mathrm{ml}$ of distilled water). This reagent highlights the contrast and heterogeneity of silicon content, Fig. 10. The different colors reflect the differences in chemical composition of silicon content. The effect of segregations with silicon on the hardness values of ductile iron is also shown in Fig. 10. The measurements of hardness of ferrite matrix were performed into 52 points. We found that hardness values were between 235 and 287 HV (20\% of difference). This difference is due to the silicon content which is important around the graphite nodules (maximum hardness) and low at joints of eutectic cells (white zones), Fig. 10. It is clear that the material hardness was improved by increasing silicon content as well as the residual pearlite (330 HV) observed in certain zones (Fig. 10). 
a

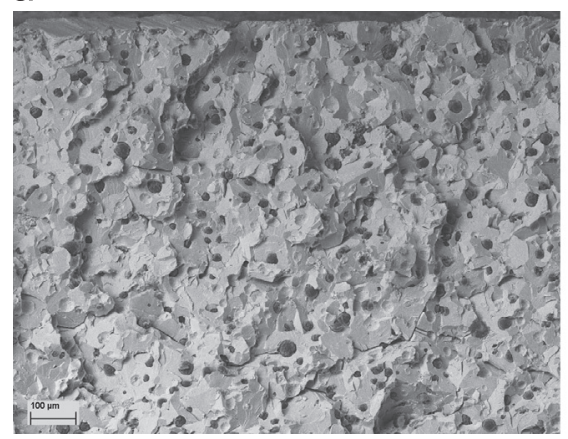

b

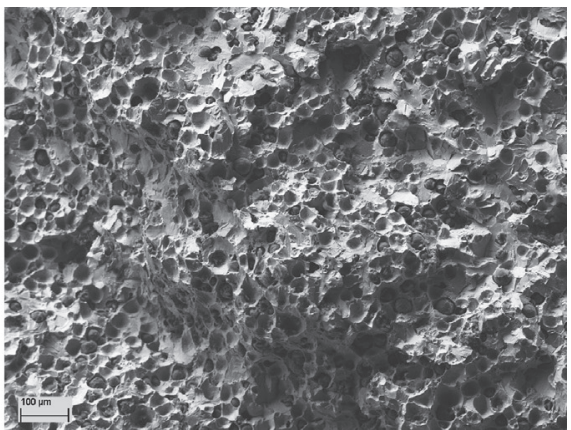

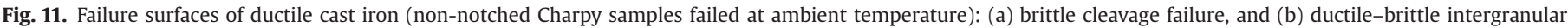
failure.

a

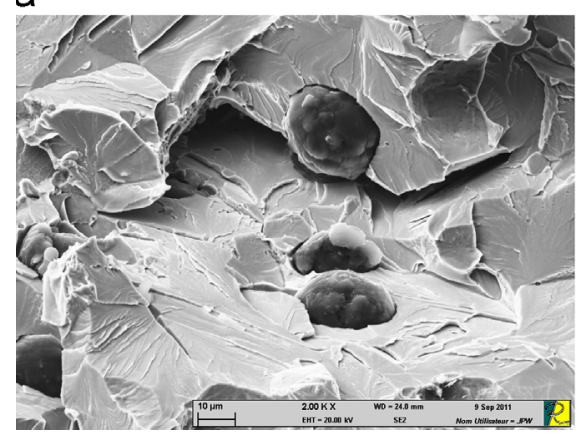

b

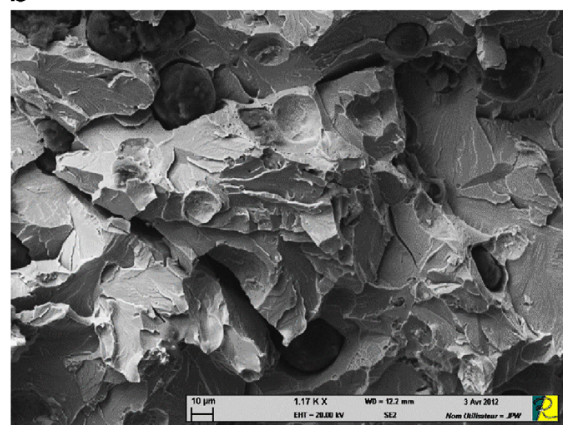

Fig. 12. Matrix/nodules decohesion and crackes in ductile iron (images 'a and b' represent two analysis zones).

\subsection{Failure surfaces analysis}

The analysis of fracture surfaces was carried out firstly with the naked eye. We observed two distinct areas: a majority bright clear area and a dark area. These both zones were then observed with a scanning electron microscope, Fig. 11. This figure shows the fracture surfaces of Charpy specimens. The different percentages of silicon influence the failure mode. The image on the left taken from the bright area (Fig. 11a) shows the brittle fracture mode by cleavage (intragranular rupture). The other image on the right taken from the dark area (Fig. 11b) shows differently these failure surfaces. Microvoids were observed and the failure mode seems to be ductile-brittle intergranular.

It has been shown that the high silicon content caused a severe drop in the material resistance to the impact energy. In addition, the presence of few poor graphite nodules could also lead to brittle cleavage failure. Without going beyond this analysis, we can already say that there were important local changes in the material, even within the same specimen. It is therefore possible that the dispersion of measured resilience values comes from this type of local deformations in iron.

\subsection{Initiation and propagation of cracks}

Defects are initially present in the casting materials which differ in their form, size, chemical composition and location. Micro-cracks initiate from segregations, inclusions and microcavities. They propagate to a large size before coalescing and forming a major crack which leads to failure of material.

The segregations of silicon concentrated highly around graphite nodules weaken the interface between ferritic matrix and graphite nodules, Fig. 12. The weakness of cohesion and the elimination of bonding forces decrease mechanical properties.
The applied load causes the displacement of dislocations (defects susceptible to initiate microplasticity) [24] and initial deformations concentrate at the graphite nodules-matrix interface. The propagation of these cavities, acting as stress concentrators, gives a fibrous aspect to the fracture surface [25]. In ductile iron, the crack propagation path goes across the weakest zone where the intensity of silicon segregation is high, Fig. 12.

It is therefore possible to make a relationship between the low resilience of some specimens, which did not achieve the minimum required value, and the cracks initiated from defects or heterogeneity of chemical composition.

\section{Conclusions}

We studied the influence of silicon on the microstructure and mechanical properties of ferritic ductile cast iron. The following results were obtained:

1) Increasing silicon content in ductile iron increased the material tensile strength and decreased its ductility and the impact energy necessary to failure.

2) All minimum required values of mechanical properties were achieved with increasing silicon content in the range of $0.125-$ $0.25 \%$. Beyond this last value, material presented a worse behavior.

3) Varying the chemical composition of silicon did not affect the ferrite grain size.

4) Metallurgical characterizations showed that the silicon was highly segregated around graphite nodules and little along the joints of eutectic cells. This important gradient is the origin of the initiation and propagation of cracks. It is possible to conclude that a high silicon content favorites brittle cleavage fracture. 


\section{Acknowledgments}

The authors gratefully acknowledge SIMAFOND project partners, particularly the 'Société Industrielle des Fontes (SIF)' that provided necessary materials and contributed to the success of this study. We also thank the funders of the study: Region of Picardy, OSEO, ITRANS pole and the European Union.

\section{References}

[1] NF EN 1563, Founding - Spheroidal Graphite Cast Irons, AFNOR, 2012.

[2] QIT-Fer et Titane Inc., Ductile iron data for design engineers, Rio Tinto Iron \& Titanium, Montréal, 1990.

[3] C. Labrecque, M. Gagné, Can. Metall. Q. 37 (5) (1998) 343-378.

[4] H.T. Angus, Cast Iron: Physical and Engineering Properties, 2nd ed., Butterworth, 1978

[5] C.A. Cooper, R. Elliott, R.J. Young, Acta Mater. 50 (2002) 4037-4046.

[6] M. Hatate, T. Shiota, N. Takahashi, K. Shimizu, Wear 251 (2001) 885-889.

[7] W.L. Bradley, M.N. Srinivasan, Int. Mater. Rev. 35 (1990) 152-155.

[8] T.M. Rowley, International Atlas of Casting Defects, American Foundrymen's Society, Schaumburg, Illinois, 1993.

[9] Y. Iwabuchi, H. Narita, O. Tsumura, Res. Rep. Kushiro Natl. Coll. 37 (2003) 1-9.
[10] K.F. Nilsson, V. Vokál, Mater. Sci. Eng. A 502 (2009) 54-63.

[11] P. Chaengkham, P. Srichandr, J. Mater. Process. Technol. 211 (2011) 1372 1378.

[12] J. Khalil-Allafi, B. Amin-Ahmadi, J. Iron Steel Res. 18 (2011) 34-39.

[13] G. Toktaş, M. Tayanç, A. Toktaş, Mater. Charact. 57 (2006) 290-299.

[14] American Foundrymen's Society, Ductile Iron Handbook, 1999, pp. 87-109.

[15] R.A. Gonzaga, J.F. Carrasquilla, J. Mater. Process. Technol. 162-163 (2005) 293-297.

[16] NF EN ISO 6892-1, Matériaux métalliques-Essai de traction, AFNOR, 2009.

[17] NF EN ISO 148-1, Essai de flexion par choc sur éprouvette Charpy, AFNOR, 2011.

[18] C.H. Hsu, K.T. Lin, Mater. Sci. Eng. A 528 (2011) 5706-5712.

[19] E. Dorazil, Austempered Ductile Iron, Academia, Praha, 1991

[20] A. Alhussein, J. Capelle, J. Gilgert, A. Tidu, S. Hariri, Z. Azari, Eng. Fail. Anal. 27 (2013) 1-15.

[21] A. Alhussein, J. Capelle, J. Gilgert, S. Dominiak, Z. Azari, Int. J. Hydrogen Energy 36 (2011) 2291-2301.

[22] X. Chen, Y. Li, Mater. Sci. Eng. A 444 (2007) 298-305.

[23] J.P. Chobaut, Hétérogénéité de la transformation bainitque dans les fontes à graphite sphéroïdal dans l'intervalle de températures de traitement $300{ }^{\circ} \mathrm{C}$ $400{ }^{\circ} \mathrm{C}$ (Ph.D. thesis), INPL, Nancy, France, 1987.

[24] A. Ezanno, Caractérisation rapide des propriétés à la fatigue à grand nombre de cycles des matériaux de fonderie à partir d'essais d'auto-échauffement: application aux alliages d'hélices marines (Ph.D. thesis), ENSTA, Brest, France, 2011.

[25] R.A. Martínez, Eng. Fract. Mech. 77 (2010) 2749-2762. 